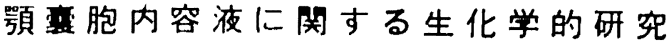

$$
\text { 金整大 }
$$

\section{Biochemical studies on cystic fluid of the jaws}

\author{
Isao KANEKo
}

\section{1. 楮䡒}

顎哓胞を最初に停怴したのは Scultetus（1654）と伝 えられているかがそそれ以米ききわて多数の症例報公， 臨床的研究ならび病理学的研究の戊果の報告がみられ， それらの棐消によって，現在では罘整胞はかなり整然と いくつかの種類に分類されている.この分類は 主として病理組織学的䂤究の㫟盤の上に, 発生 部位などの臨床面からの㭘尉を加味してなされ

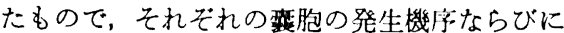
発育についても追求されているのであるが， だ十分には解決されていない多くの問題点が残 されている.これらの問題点を解明していくた めには，裂壁および周用組穖のさらに詳細な形 態学的ならびに機能的な検叶と，襄胞内に眝溜 する内容液についての生化学的検討が必要と思 われる。

しかし，䫑㐮胞の内容液に関する生化学的研 究は少なくわが国では，深江 (1931) 2)の口腔 底類表皮整胞の内容についての分析結果の報告 か最初のよらで，その後は，内外で症例報告の 中に内容液の分析結果が記载されているものか みられるのであるか，分析項目打よび分析方法 がまちまちで，系統だった研究はきわめて少な い.

そこで著者は孪胞内容液を生化学的に検討す ることによって，その由来の解明への道の一端 が開かれ，また，このことは靧覆胞の臨床的鑑 別診断に役立つのではないかと考之て，数種の 䫇喓胞内容液の生化学的分析を行ない，一応の 成績が得られたので，その結果を報告する。

東京医科科大学楼学部第 2 口腔外科学教室（主任 伊藤秀夫教授)

Second Department of Oral Surgery, School of Dentistry, Tokyo Medical and Dental Univesity (Chief : Prof. Hideo Ito)

\section{2. 研究材料}

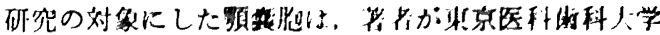

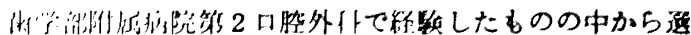

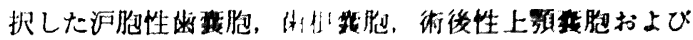

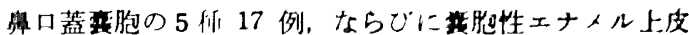

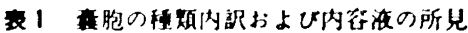

\begin{tabular}{|c|c|c|c|c|c|c|c|}
\hline 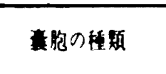 & 番号 & $\begin{array}{l}\text { 年命括 } \\
\text { LU性 }\end{array}$ & 色 諳 & 消河 & 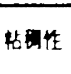 & $\begin{array}{c}\text { Cbolest ero } \\
\text { 剒 }\end{array}$ & $\begin{aligned} \because A z \\
01\end{aligned}$ \\
\hline \multirow{6}{*}{ 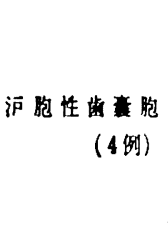 } & 1 & 27男 & 黄色 & 清 & H & - & 5 \\
\hline & 2 & 28男 & 淡黄色 & 消 & \pm & - & 1.0 \\
\hline & 3 & 36男 & 黃裸色 & 清 & + & - & 1.5 \\
\hline & 4 & 18男 & 溢色 & 混 河 & + & $H$ & 3 \\
\hline & 5 & 71男 & 黄土色 & 清 & $H$ & + & 6 \\
\hline & 6 & 8男 & 淡黄色 & 混 洨 & \pm & - & 0.8 \\
\hline \multirow{4}{*}{ 药根巷胞 (4例) } & 7 & 22男 & 类黄色 & 清 & \pm & + & 6 \\
\hline & 8 & 26女 & 貫色 & 清 & \pm & H & 3 \\
\hline & 9 & 50男 & 黄 色 & 清 & \pm & - & 2 \\
\hline & 10 & 22女 & ベージ二色 & 消 & + & - & 1.5 \\
\hline \multirow{6}{*}{$\begin{array}{c}\text { 街後性上预胞 } \\
\text { (6例) }\end{array}$} & 11 & 62女 & 黄褐色 & 混 汤 & H. & - & 4 \\
\hline & 12 & 65男 & 杀褞色 & 掍 汤 & H & - & 7 \\
\hline & 13 & 61女 & 裸色 & 掍 河 & + & $H$ & 1.0 \\
\hline & 14 & " & 赤椙色 & 清 & \pm & - & 1.3 \\
\hline & 15 & 51 女 & 植㮛色 & 混 晹 & \pm & - & 4 \\
\hline & 16 & 57男 & 杀裸色 & 混檌 & \# & $H$ & 23 \\
\hline \multirow[t]{2}{*}{ 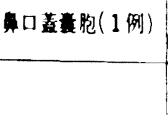 } & 17 & 27 女 & 捍 色 & 消 & H & 7 & 1.8 \\
\hline & 18 & 10男 & 黄 色 & 清 & \pm & + & 12 \\
\hline \multirow{3}{*}{$\begin{array}{c}\text { エナネル上皮堙 } \\
\text { (4 例) }\end{array}$} & 19 & 42女 & 黄土色 & 清 & + & - & 8 \\
\hline & 20 & 33女 & 黄色 & 消 & - & - & 5 \\
\hline & 21 & 57女 & ヘージ工色 & 转度白㴖 & - & - & 3 \\
\hline
\end{tabular}

注 1 . 症例 13 と14 は同一人で而側性に生したものである。

2. 粘甪性の判定は血清より低いものを一, 血清と同等のものを やや高いものを十，中等度に高いものを井，極度に高いものを 卅とした。 
腫 4 例の合計 21 例で（表 1)，いずれも瀶体团罗扣よ び組倳学的所見によって確定衫断がくだされたものであ る.な拉，症例の避択に当っては，既往歴に当䑚部位に 急性化䀟性炎の経過がなく，また，穿刺，切閒などの外 科的侵澋がなかったことを条件にし，さらに採取された 内容液に血液あるいは朖など混入がなかったものに限 定した。な拉，上記の条件を満たすものでも，内容がき わめて粘閤で pipetting が不可能なものは除外した.

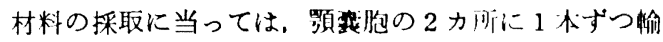
血針を穿刺し，一力から内容液を吸引すると，他方から 自然に空気が入って亦胞内が陰圧にならないようにした。

採取された内容液は，その都度，直ちに $4^{\circ} \mathrm{C}, 10,000$ $\mathrm{rpm}$ で 30 分間遠现し，得られた上清の一部について は電気泳動を行ない, 残部は $-20^{\circ} \mathrm{C}$ の冷暗所に保存し、 他の分析材料とした。

対照はそれぞれの患者の血清とした。すなわち，忠者 の前腕正中皮静脈より採血し，30 分間室温に放㯰して から，2,000 rpmで 20 分間遠沈し，得られた上清を上 記と同様な㭘索の材料とした。

\section{3. 分析項目と方法}

\section{Disc 電気泳動}

中村 ${ }^{3)}$ の方法により詝蔵試薬および実験用試薬を調整 した.

\section{貯葴試薬:}

a $1 \mathrm{~N} \mathrm{HCl} 48 \mathrm{ml}$, trishydroxymethylaminomethane (TRIS) $36.6 \mathrm{~g}, \mathrm{~N}, \mathrm{~N}, \mathrm{~N}^{\prime}, \mathrm{N}^{\prime}$-tetramethylethylendiamine (TEMED) $0.23 \mathrm{ml}$ に蒸溜水 を加えて $100 \mathrm{ml}$ とした ( $\mathrm{pH} \mathrm{8.9).}$

b $1 \mathrm{~N} \mathrm{HCl} 48 \mathrm{ml}$, TRIS $5.98 \mathrm{~g}$, TEMED $0.46 \mathrm{ml}$ に蒸溜水を加えて $100 \mathrm{ml}$ とした（pH 6.7）.

c acrylamide $28.0 \mathrm{~g}, \mathrm{~N}, \mathrm{~N}^{\prime}$-methylenebisacrylamide (BIS) $2.5 \mathrm{~g}$ に蒸溜水を加えて $100 \mathrm{ml}$ と した.

d acrylamide $10.0 \mathrm{~g}$, BIS $2.5 \mathrm{~g}$ に蒸溜水を加えて $100 \mathrm{ml}$ とした.

e riboflavine $4.0 \mathrm{ml}$ に蒸溜水を加えて $100 \mathrm{ml}$ と した.

f 槽用眝蔵緩衝液：TRIS $6.0 \mathrm{~g}$, glycine $28.8 \mathrm{~g}$ に水を加えて $1 l$ とした.

\section{実験用試薬 :}

1) 細孔 gel 用試薬の i)：a：c：蒸溜水 の割合 を1:2:1 とした.

2) 細孔 gel 用試薬の 2): 過硫酸アンモニウム $0.14 \mathrm{~g}$ に水を加えて $100 \mathrm{ml}$ とした。

3) 粗孔 gel 用試薬： b: d: e : 蒸溜水 の割合を $1: 2: 1: 4$ とした.

4）槽用緩衝液： $\mathrm{f}$ を蒸溜水で 10 倍に希釈して使 用した。
5) 染出液： amidoblack $10 \mathrm{~B} 1 \mathrm{~g}$ を\% 附济 100 $\mathrm{ml}$ に得㑇した。

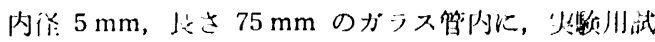

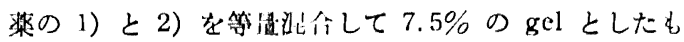
のを、下端より $60 \mathrm{~mm}$ まで入れ，その上に 3) を 10

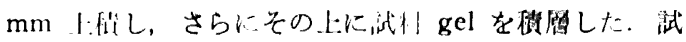
料 gel は3）の $1 \mathrm{ml}$ に顺体 $20 \mu l$ を证和して作製し, その $0.10 \mathrm{ml}$ を䏘いた，近掼は定西压で，1管当り 3 $\mathrm{mA}$ とした，冰秒よ Joule 然による影然を進けるため

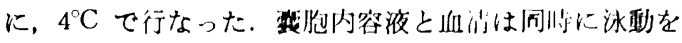
行ない, $0.001 \%$ bromophenol blue (BPB) 水復液 $1 \mathrm{ml}$

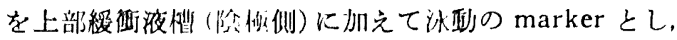
䄪 60〜90 分で終了した. 涾㽪後, amidoblack 10 B 如色

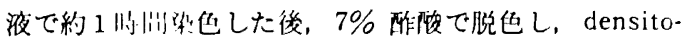
metryを行なった. densitometer は富土理研製自記濃 度钎録計 FD-IV 型を使用した。

\section{2. 棇蛋白}

総蛋白の定量は Lowry 54,5)の方法によって行なっ た. すなわち，検体の 100 倍水溶液 $3 \mathrm{~m} l$ にアルカリ性 銅溶液 $1 \mathrm{ml}$ を混和し, 10 分放監後 Folin 試蒋 $0.1 \mathrm{ml}$ を加えて混合し，30 分後に $660 \mathrm{~m} \mu$ で比色定量した. 摽染液には Hyland 製 Special Clinical Chemistry Control Serum を使用した。

3. 䌊 cholesterol, 遊離型 cholesterol および ester 型 cholesterol

cholesterol の定量は Zak ら6)の方法によって行なっ た。すなわち, acetone-ethanol 混合液 $4 \mathrm{ml}$ に検体 $0.4 \mathrm{ml}$ を滴下混合し, $60^{\circ} \mathrm{C} 30$ 分加温した後, acetoneethanol 混合液を加えて $10 \mathrm{ml}$ としてから沪過（東洋沪 紙 No. 6 を使用) した。この抽出沪液の $0.5 \mathrm{ml}$ を蒸発 乾固した後 cholesterol を定量した。 また抽出沪液 1.0 $\mathrm{ml}$ を室温で $1 / 3$ 容に蒸発濃縮し, digitonin 溶液 0.5 $\mathrm{ml}$ を加之, 振得後 30 分間室温に放固し, $4^{\circ} \mathrm{C} 3,500$ rpm で 30 分間遠沈した. 沈榃を acetone-ether 混合 液で洗淮後，同様に遠沈し，得られた沈査について遊離 型 cholesterol を定量した. なお， ester 型 cholesterol の量は総 cholesterol と遊離型 cholesterol との差から 求めた.

\section{4. hexosamine}

hexosamine は Boas ${ }^{7)}$ の変法で定量した.すなわち 検体を $2 \mathrm{~N} \mathrm{HCl}$ 中で減圧封管し, $100^{\circ} \mathrm{C}$ で 15 時間加 水分解し, Dowex $50 \mathrm{~W} \times 8$ (H type, 200 400 mesh) のカラム $(10 \mathrm{~mm} \phi \times 40 \mathrm{~mm})$ に通し, 蒸溜水で洗㹋後, $2 \mathrm{~N} \mathrm{HCl} 10 \mathrm{ml}$ で溶出し，その $2 \mathrm{ml}$ を発色させた。標 準液は生化学工業製 D-glucosamine hydrochloride (特 級)を用いて調製した。

\section{5. 電解算}

$\mathrm{Na}$ およびKの定量は炎光分析によって行なった。す なわち，検体を再蒸溜水で 51 倍に希釈し，Evans 炎 
光光度計を使用して， $\mathrm{Na}$ は波艮 $589 \mathrm{~m} \mu ， \mathrm{~K}$ は波長 $768 \mathrm{~m} \mu$ のフィルターで测定した.

$\mathrm{Cl}$ は Folin-Wu の除蛋白（桧体 $0.5 \mathrm{ml}+1 / 12 \mathrm{~N} \mathrm{H}_{2} \mathrm{SO}_{4}$ $4 \mathrm{~m} l+10 \mathrm{~g} / \mathrm{dl}$ タングステン酸ナトリウム $0.5 \mathrm{ml}$ )を行な った後に遠沈し，上清 $2.0 \mathrm{ml}$ をとり, Schales-Schales 法8)により定量した。

なお，電解質の定量に当っては，陚韯調㘹，器具洗沎 に再菽溜水を使用した。

\section{4. 分 析 結 果}

\section{Disc 電気泳動による蛋白分画}

分離された蛋白分画の名称は中村 ${ }^{8)}$,8) の血漃蛋白分画 の名称にしたがい，以下のようにした。

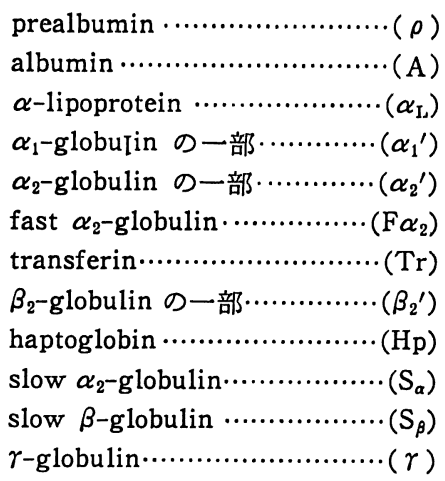

血清では蛋白分画の分離が明膫で，全例が正常と思わ れる泳動像を示したが，露胞内容液では分画の分離が明 瞭でないものが多く，上記全分画を数量化するのが困難 であったので, densitometry の pattern での比較にと どめた. densitometry は内容液と血清の albumin の peak の高さがほぼ一致するように描記させた.

前述したように，内容液は分画の分離が明瞭ではない むのが多く，また血清に比へて分画数の減少するものも 多かった. エナメル上皮腫以外の需胞では特にその傾向 が強く, haptoglobin の細分画の分離が認められず高台 状を示す例もあった（図1および 2). また同種の政胞 でも各分画の分離の明瞭さ，あるいは各分画の peak の 高さなどに著しい差違が認められた，血清にはみられな い特殊な蛋白分画は検出されなかった。これは gel の 濃度, $\mathrm{pH}$ あるいは緩衝液の $\mathrm{pH}$, イオン強度, また内 容液の涾動像があまり明瞭でなかったことなどによるも のかも知れない.

内容液と血清との主な相違点を要胞の種別ごとに要約 すると以下のようである.

沪胞性歯襄胞 ( 6 例)

$\rho:$ 分離が明暸でないものが多かった.

$\alpha_{\mathrm{L}}, \alpha_{1}{ }^{\prime}$ 扰よび $\alpha_{2}{ }^{\prime}$ ：分画の分離が明瞭でなく，それぞ れの peak の両翼が重複するかのよらにほぽ平坦な pattern を示し，高さも低い傾向にあった。
$\operatorname{Tr}$ : 分画の分離は明嘹であったが，対 albumin 相奶 濼度では，血清が全例はぼ正常と思われるのと対し，内 容液には高いものと低いものとがあり，その割合は半々 であった。

$\beta_{2}$ : 対 albumin 浱殿は低下する值向にあった。

$\mathrm{Hp}$ : 細分画の分䧺は明暸でないるのが多かったが, Hp 全体の pattern は组清に類似していた。

$\mathrm{S}_{\alpha}$ ：文鄙によると $\mathrm{S}_{\alpha}$ が欠损しているといら報告すあ るが，著者の分析では全例にこれが褪められた。

㐘根璂胞 (4 例)

A 扰よび $\operatorname{Tr}$ の分画の分離は比敢的盯膯であったが， その他の分画については顺件に上って分離の明膯の程度 がー定でなく，識别が图難であった，densitometry の pattern の概形は血清に類似しているか，A/G は低い硕 向を示し，特に Hp の対 albumin 浱度は血清の 2 3 倍に相当した。

$\alpha_{2}{ }^{\prime}$ と $\operatorname{Tr}$ との間に $\mathrm{F}_{\alpha}$ に相当すると思われる分画が
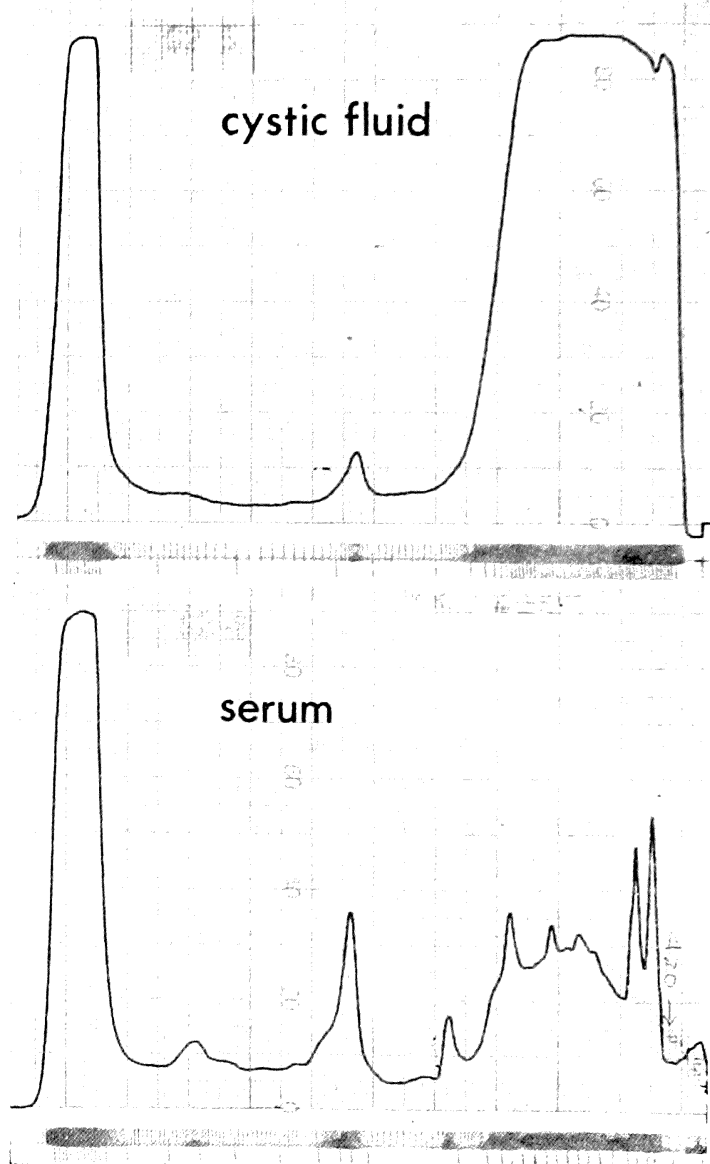

图 1 血清と著しい相違を示した歯根恶胞の 1 例 (上：内容夜, 下：血清） 


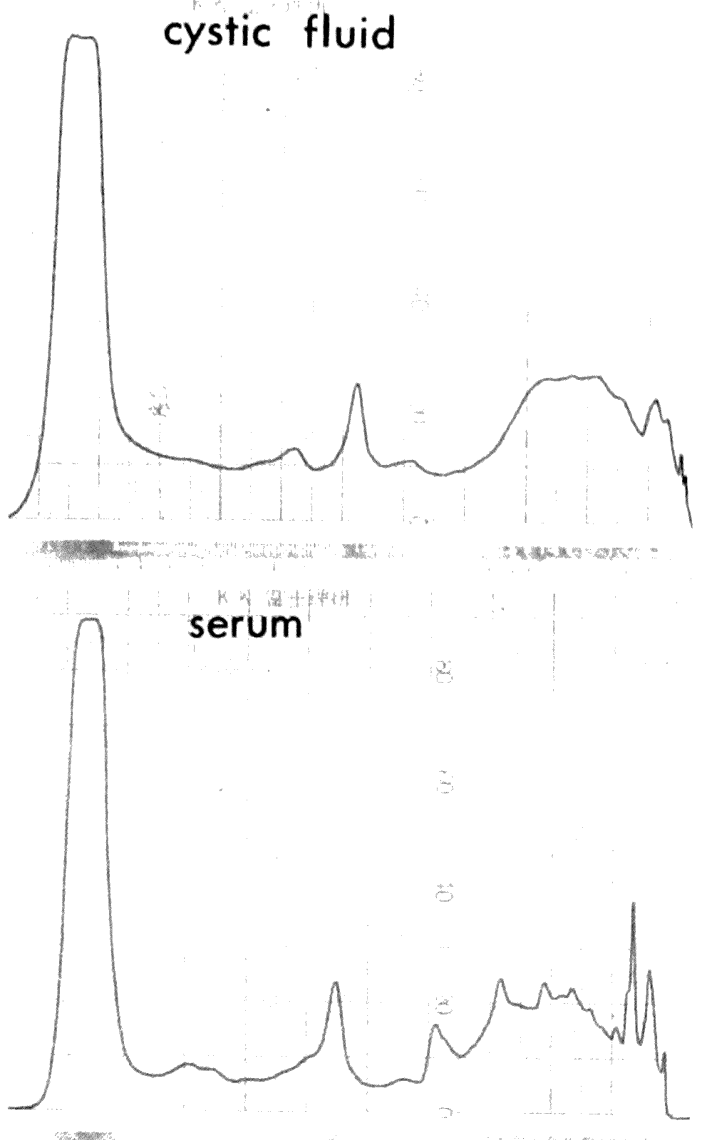

athes:

$\oplus$ 図 2 血清に比較的類似した像を示した沪胞性崡䔮胞の例 $\ominus$ (上：内容液, 下：血清）

高く出現したものが 1 例みられたが，他は $\alpha_{\mathrm{L}}$ から F $\alpha_{2}$ までほぼ平坦な pattern を示した。

Tr：血清とほぼ同等, または低い pattern を示した. $\beta_{2}{ }^{\prime}$ : 本分画の認められないるのが 1 例あり，他の 3 例は極度に明瞭さを欠き， peak の高さも低かった。

$\mathrm{Hp}$ : 血清は正常像と思われるのに対 し，内容液には 細分画の分離がみられず，上部の平坦な mono-peak の 状態を示した。

$\mathrm{S}_{\alpha}$ および $\mathrm{S}_{\beta}$ : これらが認められたのは 1 例のみで, 他の 3 例には認められなかった.

術後性上顎交胞（6 例）

歯根变胞と同様に globulin の分画か， 2, 3 の分画を 除いて明瞭でなく，識別が困難であった．特に，1例で は $\operatorname{Tr}$ がわずかに認められたが， $\alpha_{\mathrm{L}}$ 以後 $\mathrm{S}_{\beta}$ までほぼ 平坦な pattern を示するのがあった.

$\alpha_{\mathrm{L}}, \alpha_{1}{ }^{\prime}$ および $\alpha_{2}{ }^{\prime}$ : 分画の分離は認められず，ほぼ 平坦な pattern を示した.

$\mathrm{F} x_{2}$ : わずかに認められたものが 1 例で，他は認めら
れなかった。

$\mathrm{Tr}$ : 化卜をボするのが 2 例あった。 その5ち 1 例は globulin 位で平坦な pallern 位した恔倠であった。

Hp：本分政の梁められなかったものが 1 例あった。 他の 5 例は血沙と仪似の峧应 pattern を示したが，細 分画の分噰は旳䀣でなかった。

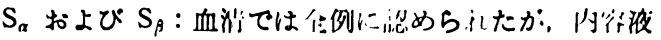
でな㣙沁められないものが 1 例あった.

口重胞 ( 1 侧)

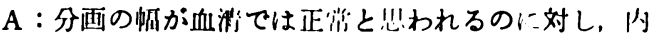
洨液では帉の拡人がみられた。これは久野ら と一致するものと思われる。

$\alpha_{\mathrm{L}}$ : 分雄が盯成でなく西翼に尼を引いたよらななた らかな pattern を示した.

$\alpha_{1}{ }^{\prime}$ および $\alpha_{2}{ }^{\prime}: \alpha_{\mathrm{L}}$ と同様になだらかな pattern で あったか，対 albumin 淟度は高かった。

$\mathrm{F} \alpha_{2}$ : 血清には認められたが，内容液には認められな かった.

$\mathrm{Hp}$ ：血清では正常と思われたが，内容液では細分画 の分截が全くみられなかった．対 albumin 濃度は血清 とほほ篎しかった。

$\mathrm{S}_{\alpha}$ および $\mathrm{S}_{\beta}$ : peak の頂点の鋭さに久け，対 albumin 濃度も低下していた。

\section{エナメル上皮琏 ( 4 例)}

4 例とも血清では正常像と思われるのに対し，分画の pattern がなたらかになったり，分画数の减少などがみ られたが，他種の鸾胞に比べると，最も血清に類似した pattern を示し, 個々のばらつきも最も少なかった.

$\alpha_{1}{ }^{\prime} ， \alpha_{2}{ }^{\prime}$ および $\mathrm{F} \alpha_{2}$ : 血清には全例に認められたか， 内容液には全例に認められなかった.

$\operatorname{Tr}$ : 対 albumin 濃度は低下の㑯向を示し，血清の約 1/2 であった.

$\beta_{2}{ }^{\prime}$ : 血清では全例正常と思われたが，内容液では全 例に認められなかった。

Hp : 血清では全例正常と思われたが，内容液では紐 分画の分雄がみられず，なたらかな mono-peak の状態 を呈した。

$\mathrm{S}_{\alpha}$ および $\mathrm{S}_{\beta}$ : 認められないものが1例あり，他は対 albumin 濃度に低下の傾向を示した。

\section{2. 絰蛋白量}

要胞内容液の総蛋白量は表 11 のように，最大 $17.2 \mathrm{~g} /$ $\mathrm{d} 1$, 最小 $4.8 \mathrm{~g} / \mathrm{dl}$ と非常に幅広い値を示した。種類別 に平均值をみると表 2 および図 3 のようで, 平均值が最

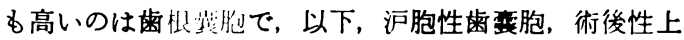

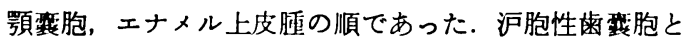
雪根变胞は偏差が非常に大きく，術後性上顎薜胞は血清 に最も近い平均値を示した，また，エナメル上皮腫は平 均値が血清の約 $2 / 3$ と低く, 偏差も非常に小さく, 他の 襄胞とは量的様相を異にしていた。 
哀 2 粉色白早 ( $\mathrm{g} / \mathrm{dl}$, mean $\pm \mathrm{SD})$

\begin{tabular}{|c|c|c|}
\hline 貫胞の程類 & 内 容 淮 & 消 \\
\hline 沪胞性为㑒胞 & $9.5 \pm 3.68$ & $8.0 \pm 1.00$ \\
\hline 齿 根 茹 胞 & $11.0 \pm 5.10$ & $8.5 \pm 0.60$ \\
\hline 術後性上濒善胞 & $8.3 \pm 1.49$ & $8.2 \pm 1.04$ \\
\hline エナメル上皮腫 & $4.9 \pm 0.10$ & $7.2 \pm 0.59$ \\
\hline 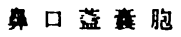 & $(10.5)$ & $(10.5)$ \\
\hline
\end{tabular}

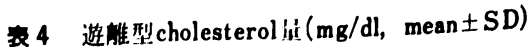

\begin{tabular}{|c|c|c|}
\hline 咅胞の㮔知 & 邖行 液 & 血 \\
\hline 汇胞性幽胞 & $172.2 \pm 168.9$ & $50.1 \pm 16.3$ \\
\hline 增 根 胞 & $90.2 \pm 71.0$ & $40.7 \pm 21.5$ \\
\hline 術後性上弱胞 & $161.3 \pm 122.1$ & $54.4 \pm 11.8$ \\
\hline エナメル1:皮压 & $64^{\circ} .2 \pm 11.10$ & $41.5 \pm 26.3$ \\
\hline 口篮胞 & $(87.9)$ & $(39.6)$ \\
\hline
\end{tabular}

$10 \quad 15 \mathrm{~g} / \mathrm{d} l$

哀 5 ester釗cholest erol $(\mathrm{mg} / \mathrm{dl}$, mean士SD)

沪胞性幽雅胞

枓 根站 胞

術後性上㹲证胞

エナメル上皮晅 四

口蓝鞋胞

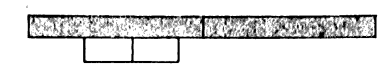
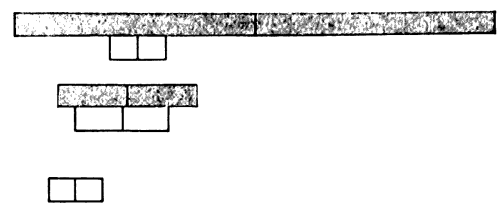

图了総蛋量

带 3 總cholesterol 量 $(\mathrm{mg} / \mathrm{dl}$, mean $\pm \mathrm{SD}$

\begin{tabular}{|c|c|c|}
\hline 熟胞の種類 & 内 容 液 & 清 \\
\hline 炉胞性歯婁胞 & $308.0 \pm 173.7$ & $184.5 \pm 17.23$ \\
\hline 齿 根 咅 胞 & $195.8 \pm 140.1$ & $170.3 \pm 36.64$ \\
\hline 術後情性碩衰胞 & $315.3 \pm 168.7$ & $207.0 \pm 36.62$ \\
\hline エナメル上皮堙 & $170.5 \pm 43.01$ & $176.5 \pm 31.31$ \\
\hline 自口蓋責胞 & (198) & (173) \\
\hline
\end{tabular}

$\begin{array}{llllll}0 \quad 100 & 200 & 300 & 400 \quad 500 \mathrm{mg} / \mathrm{d} l\end{array}$

沪胞性雪露胞

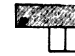

歯 根 㟟 胞

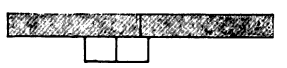

術後性上影烄胞。

エナメル上皮腫

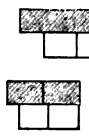

口蓝鿊胞

$$
0^{\circ}
$$

内容液

図 4 総 cholesterol 量

\section{3. cholesterol 量および ester}

内容液によって cholesterol の偏差が非常に大きいの が特徵的であった，偠胞種別にみると，表 3 および図 4

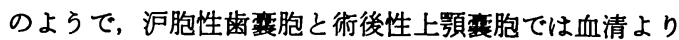
も高い平均値を示した，歯根栾胞では平均値が血清とほ ぼ等しい値であったが, 偏差は血清の約 3.5 倍であった. エナメル上皮腫は平均値, 偏差とすに血清とほぼ等しい

\begin{tabular}{|c|c|c|}
\hline 胞の洲䛡 & 内行 滩 & ili \\
\hline 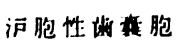 & $135.9+54.32$ & $134.5 \pm 11.15$ \\
\hline 满 根 乘 胞 & $105.7 \pm 67.25$ & $129.5 \pm 17.33$ \\
\hline 術後性上硕量胞 & $154.2 \pm 59.04$ & $152.6 \pm 28.74$ \\
\hline エナメル上皮腫 & $106.2 \pm 40.52$ & $135.0 \pm 6.86$ \\
\hline 口蓝萁胞 & (110) & (133) \\
\hline
\end{tabular}

哀 6 cholosterol ester比 $(\%$, mean $\pm S D)$

\begin{tabular}{|c|c|c|}
\hline 衰胞の種類 & 内 容 游 & in \\
\hline 沪胞性齿乘胞 & $52.2 \pm 19.17$ & $73.2=7.21$ \\
\hline 畦 根 垂 胞 & $56.1 \pm 6.20$ & $76.8 \pm 7.23$ \\
\hline 術後性上頻軍胞 & $53.9 \pm 14.55$ & B. $7 \pm 4.22$ \\
\hline エナメル上皮腫 & $60.9 \pm 9.80$ & $77.9 \pm 10.86$ \\
\hline 口蓋重胞 & $(55.6)$ & $(77.1)$ \\
\hline
\end{tabular}

0

50 $100 \%$

沪胞性犆胞

幽朴裂胞

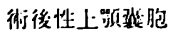

エナメル上汥䢁

奥口萿琵胞

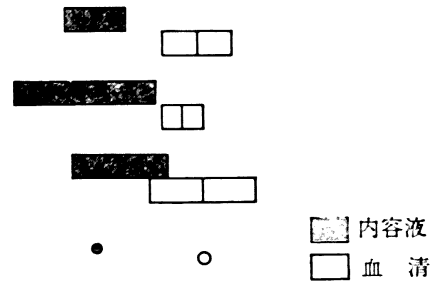

因 5 cholesterol ester 比

值を示し, 総 cholesterol でも前 3 者の垡胞とは相違が あるよらに思われた。

cholesterol を遊離型と ester 型に分けてみると，表 4 および表 5 のよらで, これを ester 比になおしてみ

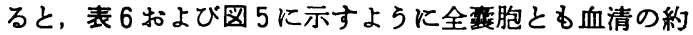
$70 \%$ と低く，明らかな差が認められた。

4. hexosamine 量

内容液では hexosamine 量も非常に大きい偏差を示 した. 最大は術後性上䫛変胞の $306.0 \mathrm{mg} / \mathrm{dl}$ であった. 
产 7 hexosamine $\mathbf{f}(\mathrm{mg} / \mathrm{dl}$, mean $\pm \mathrm{SD})$

\begin{tabular}{|c|c|c|}
\hline 基胞の種頪 & 内 容 液 & 血 \\
\hline 沪胞性歯乘胞 & $141.2 \pm 77.13$ & $92.8 \pm 6.72$ \\
\hline 歯 根 衰 胞 & $144.5 \pm 44.57$ & $85.8 \pm 8.46$ \\
\hline 術後性上穎㭟胞 & $200.4 \pm 85.40$ & $89.6 \pm 6.78$ \\
\hline エナメル上皮腫 & $89.4 \pm 19.70$ & $85.3 \pm 1.22$ \\
\hline 蓋粪胞 & $(268)$ & $(90.0)$ \\
\hline
\end{tabular}

$\begin{array}{llllll}50 & 100 & 150 & 200 & 250 & \mathrm{mg} / \mathrm{dl}\end{array}$

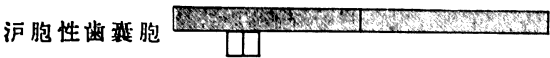

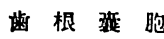

術捘性上款哓胞

エナメル上皮近

口蓝菲胞。

図 6 hexosamine 量

衰 $8 \mathrm{Na}$ 量 $(\mathrm{mEq} / \mathrm{l}$, mean $\pm \mathrm{SD})$

\begin{tabular}{|c|c|c|}
\hline 粪胞の種類 & 内 容 液 & 清 \\
\hline 沪胞性齿樭胞 & $140.6 \pm 5.94$ & $143.8 \pm 3.10$ \\
\hline 雪 根 萁 胞 & $142.0 \pm 4.36$ & $144.2 \pm 5.23$ \\
\hline 術後性上額衰胞 & $144.2 \pm 17.7$ & $144.4 \pm 3.38$ \\
\hline エナメル上皮腫 & $142.2 \pm 4.45$ & $144.8 \pm 3.44$ \\
\hline 口蓋㲤胞 & $(142.0)$ & $(146.1)$ \\
\hline
\end{tabular}

\begin{tabular}{rrrrr}
120 & 130 & 140 & 150 & $\mathrm{mEq} / l$ \\
\hline
\end{tabular}

沪胞性海葆胞

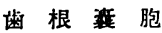

एक.

術後性上額轵胞

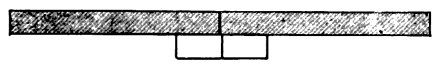

エナメル上皮腫

鮙口蒀胞

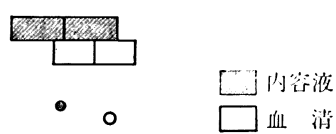

图 $7 \mathrm{Na}$ 量

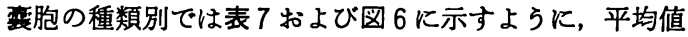

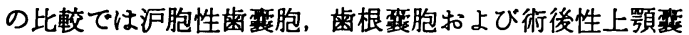
胞は血清の $1.5 \sim 2.2$ 倍と高く, 鼻口蓋要胞も3 倍と高 値を示した. エナメル上皮腫は $89.4 \pm 19.70 \mathrm{mg} / \mathrm{dl}$ で ほぼ血清に等しい数値であった。

\section{5. 電解買}

$\mathrm{Na}, \mathrm{K}$ および $\mathrm{Cl}$ についてはそれぞれ表 8，9 および 10,ならびに図 7,8 および 9 に示した. 電解質は, 各
2 9 lif $(\mathrm{mEq} / \mathrm{l}$, mean $\pm \mathrm{SI})$

\begin{tabular}{|c|c|c|}
\hline 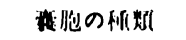 & 内 行波 & IIll \\
\hline 沪胞恻: 唯胞 & $3.69 \pm 0.469$ & $3.91 \pm 0.507$ \\
\hline 杫 胞 胞 & $3.45 \pm 0.518$ & $3.96 \pm 0.267$ \\
\hline 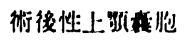 & $3.57 \pm 1.29$ & $3.73 \pm 0.298$ \\
\hline エナメル |友顺 & $\begin{array}{c}3.74 \pm 0.399 \\
(3.70)\end{array}$ & $\begin{array}{c}3.82 \pm 0.603 \\
(3.71)\end{array}$ \\
\hline
\end{tabular}

$\begin{array}{lll}2.0 & 3.0 & 4.0\end{array}$ $5.0 \mathrm{mEq} / l$

沫胞性嵝胞

幽性胞

術後性: 上:影㗪胞

エナメル上皮胉

自口登距胞

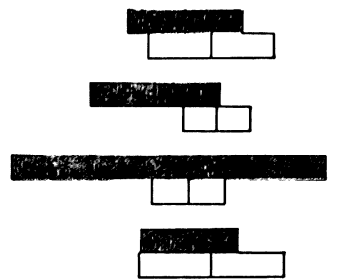

8

谓内液

图 $8 \mathrm{~K} \quad$ 量

哀10 Cl量 $(\mathrm{mEq} / \mathrm{l}$, mean $\pm \mathrm{SD})$

\begin{tabular}{|c|c|c|}
\hline 輂胞の種類 & 内 㝑 液 & IIII \\
\hline 沪胞性棦胞 & $105.6 \pm 7.57$ & $108.2 \pm 3.97$ \\
\hline 幽 根 胞 & $111.0 \pm 2.89$ & $107.8 \pm 1.54$ \\
\hline 術後性上颣腄胞 & $107.4 \pm 5.42$ & $105.3 \pm 3.28$ \\
\hline エナメル上皮腫 & $109.2 \pm 4.23$ & $109.4 \pm 0.48$ \\
\hline 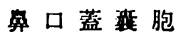 & (110.1) & (107.5) \\
\hline
\end{tabular}

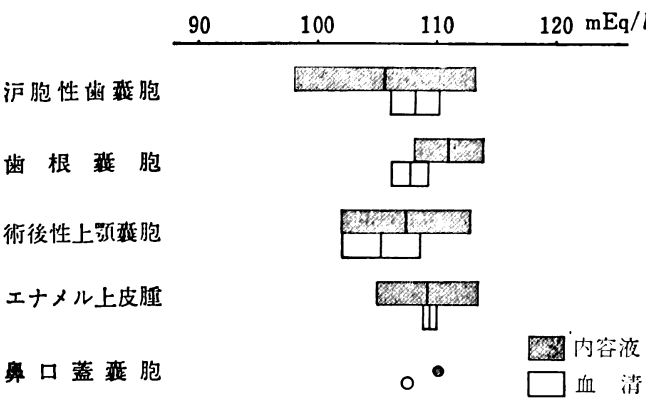

图 $9 \mathrm{Cl}$ 量

種变胞間に特別の差違は認められなかった。一般に内容 液の電解質は血清に比べて大きい偏差を有していた，平 均値の比較では， $\mathrm{Na}$ および $\mathrm{K}$ は全体的に血清より低か ったが, $\mathrm{Cl}$ は沪胞性歯整胞でやや低く，他はほぼ等し いか, やや高い傾向を示した.

総蛋白量, hexosamine 量, cholesterol 量および電 
股各胞の分析結果

\begin{tabular}{|c|c|c|c|c|c|c|c|c|c|c|c|c|c|c|c|c|c|c|c|c|}
\hline \multirow{3}{*}{ 衰胞の種類 } & \multirow{3}{*}{ 柴号 } & \multirow{2}{*}{\multicolumn{2}{|c|}{ 紇骄白 }} & \multicolumn{8}{|c|}{ cholest érol $(\mathrm{mg} / \mathrm{dl})$} & \multirow{2}{*}{\multicolumn{2}{|c|}{$\begin{array}{l}\text { hexosam- } \\
\text { ne(mg/dl })\end{array}$}} & \multirow{2}{*}{\multicolumn{2}{|c|}{$\begin{array}{c}\mathrm{Na} \\
(\mathrm{mEq} / \mathrm{l})\end{array}$}} & \multirow{2}{*}{\multicolumn{2}{|c|}{$\begin{array}{c}\mathrm{K} \\
(\mathrm{mEq} / \mathrm{l})\end{array}$}} & \multirow{2}{*}{\multicolumn{2}{|c|}{$\begin{array}{c}\mathrm{Cl} \\
(\mathrm{mEq} / \mathrm{l})\end{array}$}} & \multirow{3}{*}{ 番号 } \\
\hline & & & & \multicolumn{2}{|c|}{ tobolesterol } & \multicolumn{2}{|c|}{ 遊篗型 } & \multicolumn{2}{|c|}{ rest er 型 } & \multicolumn{2}{|c|}{ est ter $(\%)$} & & & & & & & & & \\
\hline & & 内容做 & 血清 & 内容液 & 血消 & 内谷㳔 & 血消 & 队容液 & 出消 & 内寉湤 & 血消 & 内容湖 & 血消 & 内浴脑 & 血消 & 内德液 & 血清 & 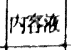 & 血请 & \\
\hline \multirow{6}{*}{ 沪胞性齿車胞 } & 1 & 16.4 & 8.4 & 598 & 159 & 500 & 39.2 & 98.0 & 120 & 16.4 & 75.3 & 274.0 & 86.3 & 129.1 & 149.4 & 3.72 & (4.45 & 90.5 & 104.4 & 1 \\
\hline & 2 & 9.6 & 9.7 & 121 & 167 & 33.0 & 24.8 & 88.0 & 142 & 72.7 & 85.1 & 101.2 & 92.4 & 143.5 & 144.4 & 3.66 & 3.33 & 109.9 & 109.4 & 2 \\
\hline & 3 & 9.7 & 7.5 & 321 & 201 & 164 & 50.3 & 157 & 151 & 48.9 & 75.0 & 125.8 & 97.2 & 142.8 & 143.1 & 4.05 & 3.23 & 109.3 & 115.5 & 3 \\
\hline & 4 & 7.3 & 7.7 & 402 & 192 & 169 & 55.2 & 233 & 137 & 57.9 & 71.3 & 66.4 & 97.7 & 146.0 & 141.2 & 2.78 & 4.34 & 105.0 & $\{107.5$ & 4 \\
\hline & 5 & 8.0 & 8.0 & 226 & 198 & 88.9 & 71.2 & 137 & 127 & 60.7 & 64.0 & 188.2 & 100 & 140.6 & 143.9 & 4.01 & 3.91 & 108.8 & 106.2 & 5 \\
\hline & 6 & 5.9 & 6.8 & 181 & 190 & 78.3 & 59.8 & 102 & 130 & 56.7 & 68.5 & 91.5 & 83.4 & 141.5 & 140.8 & 3.89 & 1.20 & 110.2 & 105.9 & 6 \\
\hline 均 & & 9.5 & 8.0 & 308.0 & 184.5 & 172.2 & 50.1 & 135.9 & 134.5 & 52.2 & 73.2 & 141.2 & 92.8 & 140.6 & 143.8 & 3.69 & 3.91 & 105.6 & 108.2 & \\
\hline \multirow{4}{*}{ 告 根 萁 胞 } & 7 & 17.2 & 9.4 & 97.0 & 155 & 40.7 & 24.8 & 56.3 & 130 & 58.0 & 84.0 & 193.7 & 84.6 & 142.9 & 146.1 & 3.89 & 4.26 & 111.0 & 108.5 & 7 \\
\hline & 8 & 12.9 & 8.4 & 122 & 153 & 43.9 & 30.0 & 78.1 & 123 & 64.0 & 80.0 & 168.2 & 78.0 & 139.6 & 139.9 & 3.52 & 3.66 & 107.1 & 109.3 & 8 \\
\hline & 9 & 8.4 & 8.1 & 162 & 148 & 78.8 & 35.6 & 83.2 & 112 & 51.4 & 75.9 & 120.5 & 99.8 & 137.4 & 145.8 & 3.69 & 3.83 & 114.5 & 107.8 & 9 \\
\hline & 10 & 5.6 & 8.2 & 402 & 225 & 197 & 72.2 & 205 & 153 & 50.9 & 67.1 & 95.5 & 80.5 & 147.9 & 144.8 & 2.71 & 4.08 & 111.1 & 105.7 & 10 \\
\hline 均 & & 11.0 & 8.5 & 195.8 & 170.3 & 90.2 & 40.7 & 105.7 & 129.5 & 56.1 & 76.8 & 144.5 & 85.8 & 142.0 & 144.2 & 3.15 & 3.96 & 111.0 & 107.8 & \\
\hline \multirow{6}{*}{ 後誧性上歌黄胞 } & 11 & 7.0 & 8.9 & 63.8 & 245 & 26.9 & 67.3 & 36.9 & 178 & 57.8 & 72.5 & 110.0 & 87.5 & 140.8 & 142.7 & 3.41 & 3.86 & 112.8 & 100.4 & 11 \\
\hline & 12 & 10.8 & 9.0 & 491 & 248 & 317 & 59.6 & 174 & 188 & 35.4 & 76.0 & 306.0 & 96.4 & 177.4 & 150.9 & 4.17 & 3.60 & 101.3 & 105.9 & 12 \\
\hline & 13 & 8.0 & 6.7 & 496 & 176 & 300 & 35.6 & 196 & 140 & 39.5 & 79.8 & 224.3 & 84.3 & 145.6 & 141.8 & 4.05 & 3.77 & 107.4 & 104.0 & 13 \\
\hline & 14 & 6.8 & $"$ & 241 & $"$ & 79.2 & $"$ & 162 & $n$ & 67.7 & $n$ & 89.0 & . & 139.7 & , & $4 . \infty$ & , & 105.2 & - & 14 \\
\hline & 15 & 7.9 & 8.6 & 231 & 191 & 66.5 & 56.5 & 165 & 135 & 71.2 & 70.4 & 208.4 & 82.6 & $\mid 137.2$ & 145.0 & 4.68 & 4.12 & 114.9 & 107.3 & 15 \\
\hline & 16 & 9.5 & 7.7 & 369 & 175 & 178 & 53.1 & 191 & 122 & 51.8 & 69.7 & 264.4 & 97.1 & 124.6 & 141.6 & 1.08 & 3.32 & 103.0 & 108.9 & 16 \\
\hline 均 & & 8.3 & 8.2 & 315.3 & 207.3 & 161.3 & 4.44 & 154.2 & 152.6 & 53.9 & 73.7 & 200.4 & 89.6 & 144.2 & 144.4 & 3.57 & 3.73 & 107.4 & 105.3 & \\
\hline 口篮苝胞 & 17 & 10.5 & 10.5 & 198 & 173 & 87.9 & 39.6 & 110 & 133 & 55.6 & 77.1 & 268.0 & 90.0 & 142.0 & 146.1 & 3.70 & 3.71 & 110.1 & 107.5 & 17 \\
\hline \multirow{4}{*}{ エナルル上皮俚 } & 18 & 4.9 & 6.4 & 218 & 152 & 73.0 & 18.9 & 145 & 133 & 66.5 & 87.6 & 80.0 & 85.8 & 136.8 & 140.0 & 3.50 & 3.23 & 108.5 & 109.9 & 18 \\
\hline & 19 & 5.0 & 7.7 & 151 & 189 & 74.6 & 55.8 & $\pi .4$ & 133 & 50.6 & 70.5 & 115.1 & 85.4 & 141.2 & 145.0 & 3.92 & 4.37 & 104.3 & $|109.7|$ & 19 \\
\hline & 20 & 5.0 & 7.2 & 121 & 150 & 54.6 & 19.8 & 66.4 & 130 & 54.9 & 86.8 & 71.0 & 86.3 & 143.3 & 148.1 & 3.32 & 4.30 & 114.6 & 108.9 & 20 \\
\hline & 21 & 4.8 & 7.6 & 192 & 215 & 54.6 & 71.4 & 137 & 144 & 71.6 & 66.7 & 91.4 & 83.5 & 147.5 & 146.0 & 4.20 & 3.36 & 109.3 & 109.1 & 21 \\
\hline 均 & & 4.9 & 7.2 & 170.5 & 176.5 & 64.2 & 41.5 & 106.2 & 135.0 & 60.9 & 77.9 & 89.4 & 85.3 & 142.9 & 14.8 & 3.74 & 3.82 & 109.2 & 108.4 & \\
\hline
\end{tabular}

解質量の分析結果は表 11 のようであった.

\section{5. 考察}

著者が行なった䫇䪄胞の内容液についての生化学的分 析の結果は上記のよらであるが，それを，血清との対比 に主眼を括いて考察したい。

1. Disc 電気泳動による蛋白分画について

蛋白分画の泳動像は莜胞の種類による特敳は見出され ず，個々の症例によっていろいろであり，また，分離が 明瞭でない分画も多くて，これを数量化して比較するこ とが困難であった，しかし全体的にみると，albumin と の相対濃度は血清とあまり相違がなく, globulin 位の分 画数の減少と量的增加が特徵的であった。
一般に，胸水，腹水あるいは病的関節液などの出疼 は，その患者血清に類似の泳動像を呈する11)ことが多い といわれている。 しかし, 䪽霞胞の内容液では, 主とし て, globulin 位蛋白の分離があまり明暸でなく，分画 数の減少がみられた。これは責胞内に眝溜した液体成分 中の蛋白恃日が経過するにつれて次第に変性し，破壊 されるためであろらが，それにしても，分画の pattern は血清のそれとは多少異なっているので，内容液中の蛋 白成分が単に血清の渗出あるいは組織液の沪出によるも のたけではなくて，謷壁組織特に整壁上皮もその生成に 関与しているらしいことも考虑する必要があるように思 われる.

Toller ${ }^{1)}$ は歯根垔胞内容液の zone 電気浅動を行なっ 
て, 内容液中には分子量の大きい蛋白は娍少する㑯向が みられ，最も分子量の大きい $\alpha$-globulin は欠如してい るか，あるいは非常に少量になっており，小さい分子量 の albumin は血清とほぼ同量であったことから，暨 が分子量の大きさによって蛋白を選択透過させているの ではないかと推測している，著者の成縜です，汪之んど の粟胞に共通的に $\alpha_{1}, \alpha_{1}{ }^{\prime}$ および $\alpha_{2}{ }^{\prime}$ が減少しており， Toller の成續に類似していた，しかし，これを暨の 選㘮透過性で説明するには資料が不足であり，さらに多 くの検討が必要のよらに思われる.

な扰，Disc 電気涾動を行なった茂木ら ${ }^{(1)}$ は，沪胞性

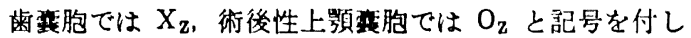
た高濃度の限局性の分画か： $\gamma$-globulin 頒城に出現した と述へているが，本研究では，同種の貿胞にも，また他 種の藏胞にも，それに相当する分画像はみられなかった。 また，楮方ら ${ }^{12}$ は $\mathrm{S}_{\alpha}$ が認められなかった沪胞性葓胞 の症例を報告しているか，著者の沪胞性雪烡胞の 6 例中 にはその上らな症例はなく根胞の 4 例中 3 例, 術後 性上䋶衰胞の 6 例中 1 例およびェナメル上皮腫の 4 例中 1 例に $\mathrm{S}_{\alpha}$ および $\mathrm{S}_{\beta}$ の欠如がみられた。

\section{2. 総蛋白について}

領変胞に関する症例報告の中には，内容液中の総蛋白 量の測定結果が記載されているものがみられるが(13) 18) 測定方法の記載がないものが多く，また，測定値に広い 分布がみられるようである（表 12），著者は予備実験と して, 顎襄胞中の総蛋白量を通常の血清生化学検查に用 いられている屈折計で測定し，一方 Lowry 法で測定し た結果と比較検討したか，両者の間に相関関係は得られ

衰12諸家の報告による総蛋白量

\begin{tabular}{|c|c|c|}
\hline 潠胞の種類 & 蛋 白 量 & 報 告 \\
\hline 沪胞性歯軎胞 & $8.25 \mathrm{~g} / \mathrm{dl}$ & 人木田ら1961 13) \\
\hline " & $6.8 \mathrm{~g} / \mathrm{dl}$ & 緒方ら1964 12 \\
\hline 棦 根 胞 & $10.0 \mathrm{~g} / \mathrm{dl}$ & 饭沼ら $1969^{10}$ \\
\hline maxillary sinus cyst & $4.8-6.7 \mathrm{~g}$ & Tchedmir ら $1965^{15}$ \\
\hline 類表皮䧶胞（顥骨） & $3185 \mathrm{mg} / \mathrm{dl}$ & 長尾ら1962 17 \\
\hline 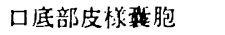 & $5.1 \mathrm{mg} / \mathrm{dl}$ & 岡野ら 1961 16) \\
\hline
\end{tabular}

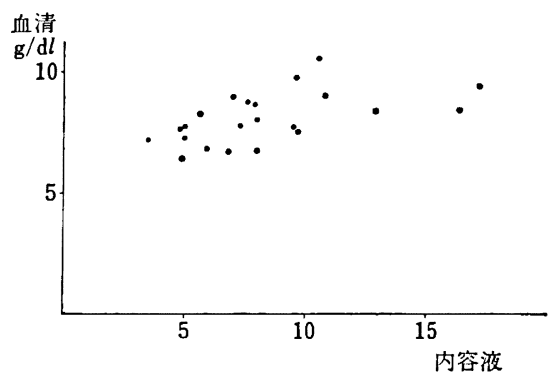

図 10 内容液の総蛋白量と血清総蛋白量の関係
なかった。これは恐らく、内容液中に分まれる嫶頪扰よ

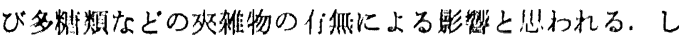
たがって，本砳究では Kjeldahl 江よりも探作扒制推で なく，しかも比校的正确に蛋自量を反叫する Lowry 沚 を採択して分析を行なった。气の絬壮は前述したよらに 垠大が $17.2 \mathrm{~g} / \mathrm{dl}$ ，最小が $4.8 \mathrm{~g} / \mathrm{dl}$ であった，汀胞性嵝

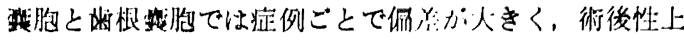

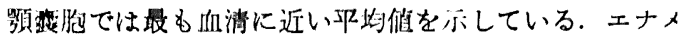
ル上皮随の平均值は折清の約 $2 / 3$ であった。

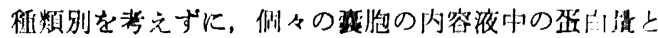

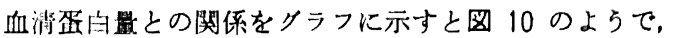
相関係数 $(r)$ は 0.53 , また, 回慣淔線は $Y=0.16 X+$ 6.71 であった．本成綪では， $\mathrm{t}$ 検定により，有意水泩 0.05 で有意の相関が得られたか，内容液の蛋白の方が 血清蛋白の変䟭幅より大きいことから，血清蛋白が内容 液中の蛋白を regulate するとは考えにくく，後者が前 者を直接的に反映するものかどうかは疑問のように思わ れる.

3. cholesterol 量およひ ester 比について

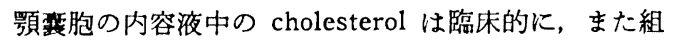
織学的にしばしば結晶として観察されることもあって， これに関する記狨は少くない，これらの中で，生化学的 定性ならびに定量の結果が記载されているのは表 13 の ようで，それをみると血清よりも高い値を示しているす のが多いようである。 また，18 例の領变胞内容液中の 総 cholesterol を定量した吉田 ${ }^{199}$ は血清にほぼ近接して いる結果が得られたと報告している（表 14）。しかし，

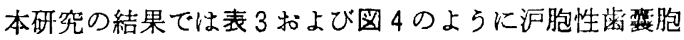

衰13諸家の報告による総cholesterol in

\begin{tabular}{|c|c|c|}
\hline 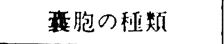 & 総cholesterol 量 & 報 告 \\
\hline 汇胞性画胞 & 定性（一） & 久木田的 $1961^{13}$ \\
\hline 㐘 根 㐞 胞 & $544 \mathrm{mg} / \mathrm{dl}$ & 邽沼的 1969 l \\
\hline maxillary sinus cyst & $48-150$ & Tchedomir is 196518 \\
\hline 類表皮䧆胞（顎骨） & $1089 \mathrm{mg} / \mathrm{dl}$ & 長尾放 1962 17 \\
\hline 口底部皮様辁胞 & 定性（卅） & 周野的 $1961^{10}$ \\
\hline 軟口蓋類皮棁素胞 & $275 \mathrm{mg} / \mathrm{dl}$ & 形浦的 $1966^{10}$ \\
\hline
\end{tabular}

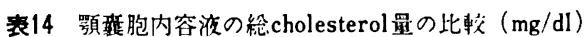

\begin{tabular}{|c|c|c|c|}
\hline \multirow{2}{*}{ 罴胞の種類 } & \multirow{2}{*}{ 吉田 $1962^{19 !}$} & 著 & 者 \\
\hline & & 内 容 液 & 血 清 \\
\hline 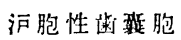 & $102-776$ ( 4 例) & $181-598$ (6 例) & $159-201$ \\
\hline 歯 根 教 胞 & $165-199$ ( 5 例) & $97.0-402(4$ 例 $)$ & $148-225$ \\
\hline エナメル上皮䜺 & $100-239$ ( 6 例) & $121-218$ (4 例) & $150-215$ \\
\hline その他の顎胞 & $93-312$ ( 3 例) & $63.8-496$ (7例) & $173-248$ \\
\hline
\end{tabular}


扰よび術後性上䫑雅胞では血清より高い㑔向が みられ、エナメル上皮妇では血消とほほ等しく， 幽根变胞では高いものと低いものとが同数であ った.

次に, 顎裂胞内容液中の cholesterol の ester 比については報告がないようで，わずかに形浦

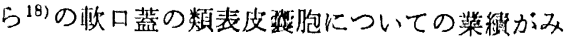
られる. それによると， ester 型 cholesterol は $30 \mathrm{mg} / \mathrm{dl}$, 连離型 cholesterol は $245 \mathrm{mg}$ / dl で，その値からester 比を求めると約 $11 \%$ であり，本研究結果と同様に逊盛型 cholesterol が增量している.

cholesterol の曲来ないしは析出機序について は，主として，病理組䄉学的站場から諭しられて いるが，また確証を得るには至っていないよらである。

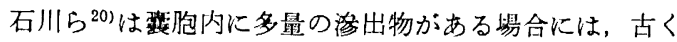
なると次第にそれらの物質の自家融解によって多量の cholesterol 結晶が析出されると述べている。 また， Counsell ${ }^{21)}$, Darlington ${ }^{22)}$, Thoma $5^{23)}$ は蒌壁の細胞, 特に上皮細胞の変性と崩壊の結果として, cholesterol が留壁組成扣よび内容液中に集稂するとしている，一方 Jacob ら ${ }^{24)}$ は血管に富んだ裂壁をもった裂胞に choles terol 結晶が著明にみられるとし，Shear ${ }^{25)}$ は慢性炎症 に伴い壁に cholesterol が沈着し，異物巨細胞反応に よって覆腔内にそれが運ばれるとしている，さらにBro-

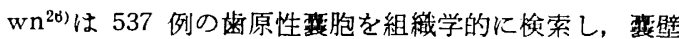
内にみられる cholesterol cleft と hemosiderin の沈着 とが発現頻度から密接に関係していると述べ, cholesterol の析出は露壁内の炎症に伴ら小出血に由来すると 推論している。 また吉田 ${ }^{19)}$ は cholesterol 增量の機序は 組織内 cholesterol の放出ではなく，むしろ桾質代謝異 常と脂質代謝え進とによる cholesterol 合成の元進に州 すべきであるとしている.このように cholesterol の析 出には種々の見解がみられるのであるか，本研究の成績 ではいずれの震胞でも ester 比の低下，すなうち遊離型 の相対的增加が認められたので，血球中の cholesterol

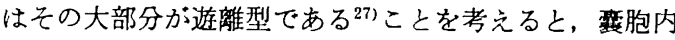
容中の cholesterol は血球由来のものも少なくない上う にも思われる。しかしまた， cholesterol が㢣胞内に眝 溜する間に，遊離型と ester 型とに破壊される速度に 美があるとすれば，経時的に ester 比も異ってくること む考えられ，この点についてはさらに詳細な検討が必要 と思われる。

罴胞内容液の cholesterol と血清の cholesterol との

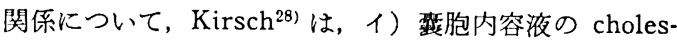
terol 值は血清のそれより高い，口）両者の cholesterol が上年するのは cholersterol の activity による，八)血 中 cholesterol の增加が，麗胞内の cholesterol deposition に関与しているかどらかは解らない，と述べてい

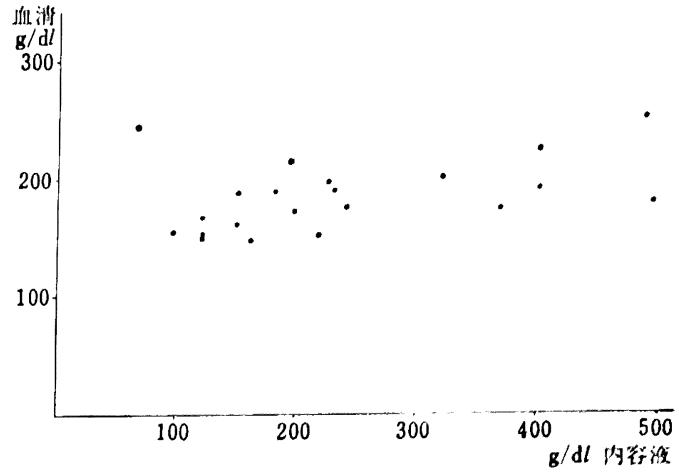

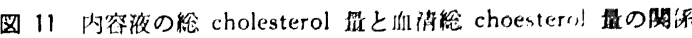

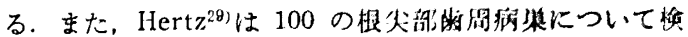

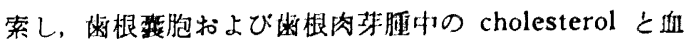
清の cholesterol との間には特に咸係は琶められないと 述へている，本研究に括ける内容液 cholesterol と组清 cholesterol との関係は国 11 のよ5で, タラフではゃや 正相四があるよらに思われるか，仆既保数（r）は 0.37 で，統計学的有意差は認められなかった. したがって。 内容液 cholesterol かi血清 cholesterol を反映する站台 は低いように思われる。

4. hexosamine について

顎霆胞内容夜中の hexosamine 量の報告はほとんど みられないようである。

本研究では，エナメル上皮腫を除く䫑西胞の Hexosamine 内容液の量は,そのはとんとが血清の 2〜3 倍に相 当し，また，内容液の肉眼的観察による粘㨄度と内容液

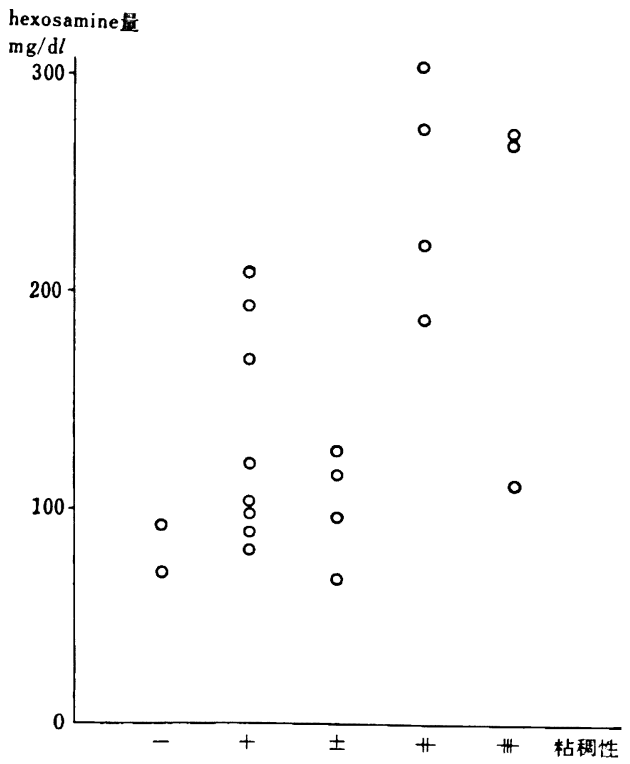

図 12 内容液の粘稠性と Hexosamine 量の関倸 
hexosamine 量との関係は图 12 のようで，粘稀度の高 いものの方が hexosamine 量も多いように思われた。 血清中の hexosamine はその大部分が protein-bound

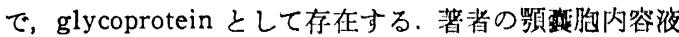
についての予借实験では， Elson-Morgan の変法30) に よるprotein-bound hexosamine と Boas 法7)による total hexosamine 量とはほぼ一致する結果が得られた とから, 内容液の hexosamine るとの大部分が glyco-

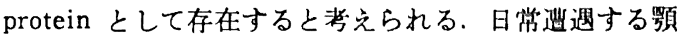
要胞の内容液は血清より粘鼠性が高いものの方が多いが， この粘稠性は恐らく内容液中の glycoprotein の量と関 係があるものと思われる。

なお，術後性上頞变胞は，その壁に円柱上皮ないし 織毛上皮の被覆の認められるものが多い31) と言われてい るが，内容液の hexosamine 量は術後性上蕦胞が最 も高い平均值を示した．このことは乑壁の上皮細胞から の分泌も内容液の一部を構成する可能性を示しているよ 5に思われる.

\section{5. 電解質について}

電解質イオンは分子量が小さく，移動しやすいので周 囲の状態を反映しやすく，また血清中では内分省系およ び自律神経系の複雑な協調によって量的，質的に比校的 狭い範囲に調節されているので，血清との関係を比較し やすい，また，細胞の内と外では，細胞膜を介して一定

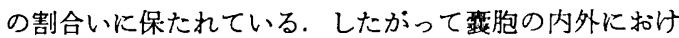
る電解質の配分を知ることにより，要壁の透過性および 壁を介しての輸送の状態を推測する手掛りの 1 つになる と思われる.

$\mathrm{Na}$ の平均値の比較では, 全覇胞にわたって内容液の 方が血清より低かった．個々の整胞別にみた内容液と血 清との $\mathrm{Na}$ の関係は図 13 のよらで, 正相関を示すが, 内容液 $\mathrm{Na}$ は血清 $\mathrm{Na}$ 上り低いるのが大部分であった。 このよ5に, 内容夜の $\mathrm{Na}$ 量は血清より低い方に傾いて いるようであるが，これを，かっては血清と同等もしく はそれ以上の濃度であったものか，長い経過の間に徐々 に希釈されたと解祀するのか，あるいは逆に，最初は血 清よりはるかに低い濃度であったものが，徐々に内容液 が濃縮するために Na 量が血清に近ついていく過程と解 釈できるのかについては，また結論が得られなかった．

$\mathrm{K}$ の平均値での比較では， $\mathrm{Na}$ と同様に内容液のほう が血清より低かったが，個々の栾胞別にみると図 14 の よらで，両者に相関は全く得られず，量比も一定しなか った．䧶胞内容液中には剝離上皮，出細胞などの細胞 成分か浮游していることが多いと言われており，細胞内 液の陽イオンの大部分を占める $\mathrm{K} か ゙$ 麗胞内容液中に放出 されることが考えられる．しかし，本研究では内容液中 のKが血清のそれより上䄯していたのは 21 例中の約半 数にすぎなかった．したがって，Kイオンは比較的自由 㴗壁を通過するか，あるいは覇壁に再吸収されること

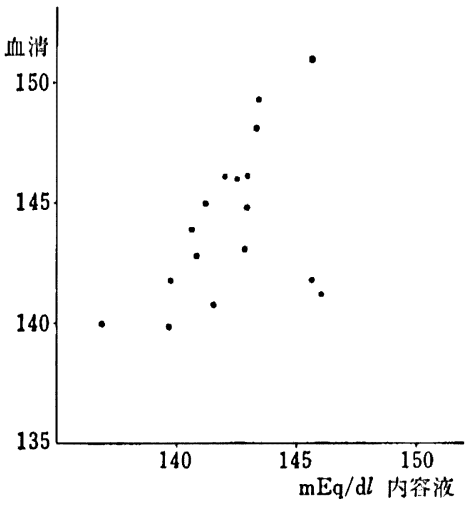

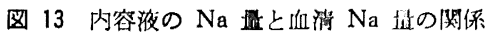
（本因の目盛りを超えるものは使宜的に除外した）

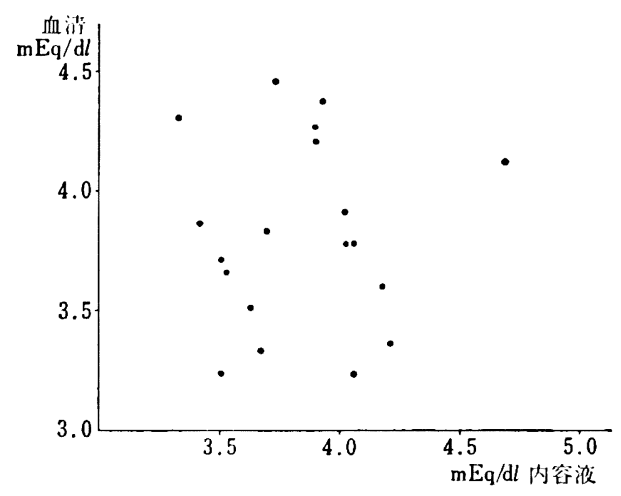

图 14 内容液のK量と血清 $\mathrm{K}$ 量との関倸 （本図の目盛りを超えるものは便宜的に除外した）

る考えられる.

$\mathrm{Cl}$ の平均値での比較では，内容液と血清との間にそ れほど差は認められなかった。個々の要胞別にみた相関 は図 15 のよ5で，相関関釈は認められず，血清 $\mathrm{Cl}$ が 105- $110 \mathrm{mEq} / \mathrm{l}$ の笨围に大部分が収まっていたのに対し， 内容液はその䇢囲を超える広い分布を示した。図 15 で 内容夜の $\mathrm{Cl}$ が $105 \mathrm{mEq} / l$ より低い部分を血清より希釈 されている部分, $105-110 \mathrm{mEq} / \mathrm{l}$ の部分を霞胞を自由に 通過して血清と平衡を保っている部分と仮定すると， $110 \mathrm{mEq} / l$ を超える部分は㱗液のように貯溜濃縮されて いる部分とも思われた。

吉田 ${ }^{19}$ は整胞内容中の $\mathrm{Cl}$ は著明に增量していて, こ の增量は組織蛋白融解により Donnan 膜平衡に基づき 体液から覇胞内に移行するためと述べている．著者の成

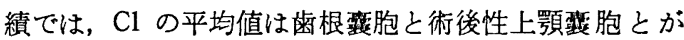
わずかに高かったか，偏差を考えると有意差は認められ 


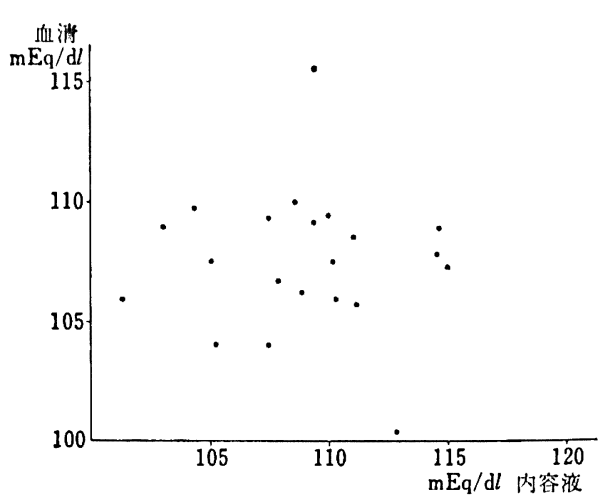

図 15 内容液の $\mathrm{Cl}$ 血消 $\mathrm{Cl}$ 堪の閶倸

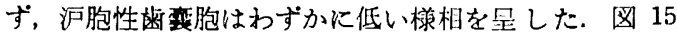
にみられるよ5に，内容液 $\mathrm{Cl}$ は血清 $\mathrm{Cl}$ に圆係なく分 布しているよらなので，両者の間に Donnan 膜平衍が 存在するといら証佐は得られなかった.

以上のように, 内容夜の電解質と血清のそれとの間に 相関関係があると思われるのは $\mathrm{Na}$ のみで，K㧊よび C は相互に無関係に分布していた。 また，個々の血清との 比較では，内容液の $\mathrm{Na}$ 值が血清の值より低いものが大 部分であり，Kは血清より高いものと低いものとが半々 で，分布範囲は 1，2 の例外はあるが，血清とほぼ同じ か，むしろやや狭いよらであった，Cl では血清より高 いとも低いとも断定できず，分布䈥囲は血清よりはるか に広かった，このように，内容液では， $\mathrm{Na}, \mathrm{K}$ 打よび $\mathrm{Cl}$ が 3 者で全く異なった様相を呈していた，しかし，内容 液中の電解質がその種類によって翼質の变動をすること は考えにくく，本研究の結果からは，内容液電解質が直 接的に血清のそれを反映するか，あるいは単純に希䣋も しくは濃縮されていくものかの結諭は得られなかった.

これらについては, 菲胞の組織学的瑇造も考虑に入れて, さらに検討をする必要があると思われる.

上記の分析結果を総合して顎衰胞内容液の生化学的性 状，および由来を考察するためには，内容液の酵素活性 ならびに糖なども考慮する必要があると思われる，著者

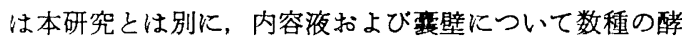
素活性と糖とを検索して扣り，その成績は追って報告す る予定であるか，現在までに得られた結果を要約する と, 以下のようである. 内容液の alkaline phosphatase (Reitman-Frankel 法, 11 例) は 0 31 Karmen 単位 で, 同一患者の血清より低いものが多く, acid phosphatase(Reitman-Frankel 法, 10 例)は0〜18.8 Karmen 単位で, 同一患者の血清より高いものが 7 例あり, 平均 値も高かった. cholin esterase (phenol-red 法, 13 例) は $0.13 \sim 0.95 \Delta \mathrm{pH}$ で, 同一患者の血清よりもわずかに 高いものが多く, また glutamic oxaloacetic transaminase[GOT]および glutamic pyruvic transaminase [GPT](いつれれ Kind-King 法, 11 例) はそれぞれ 8

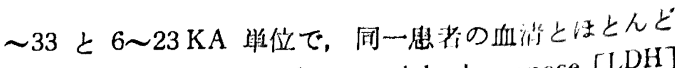
差はみられなかった. lactate dehydrogenase [LDH] (Cabaud-Wróblewski 法, 7 例)は 330 7,260 Wróble-

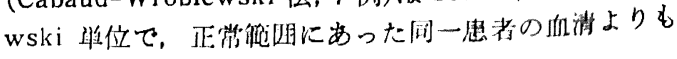
都しく䧚いものがあった。

内容液の栯（Hoffman 法，5例）の测定值は0 92 $\mathrm{mg} / \mathrm{dl}$ で，1 例は 0 值であったが，4例は同一㭧考の侐 泿とはとんと间じであり，また，fucose(Dische \& Shet・ tles 法 ${ }^{32)}$,33)，10 例）は 4.6 24.4 mg/dl で, 边消と はは等しいか，やや低い优向がみられた。

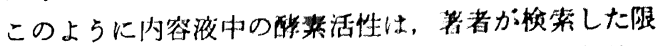

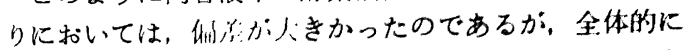

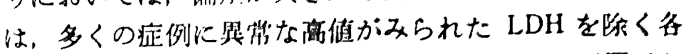
盉酸素活性扰よび精は同一患者の血清とはとんど同じか， あるいは多少低い候问にあり，むた少数ではあるが，碎 翡活性がはとんとみられない怔例むあったことなとから 考えると、これらの皟囊胞内の metabolism は多分に 狰的なるのであろらと解釈される，LDH が高储を示し

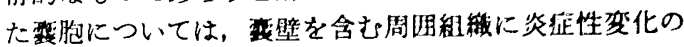
存在か疑われるのであるか，この面についてはなお㨢討 を杬けていきたい.

以上のように，靧婑胞の成り立ちおよび発育を探る手 掛りの1つとして，また，擥床的别診断に役立つ可能 性を考えて，著者は 5 種 21 例の䫇要胞の内容液を生化 学的に分析し，同一患者の血清と対比しつつ険討を進め てきた。しかし，内容液は肉眼的に種々雑多な性状を示 すと同様に，生化学的分析の結果あそれぞれの検体では らつきが大きく，わずかに教胞性エナメル上皮腫にある 程度の傾向がみられるようであったが，その他の㜔胞に ついてははとんど特改らしいものは把握できなかった。 それは靧变胞の内容液が本来多様性であることによると む考えられるが，長年にわたる経過の間に眝溜した内容 液が，それぞれに異なった種々の影韫を受けて修飾され るであろうことも無視できないし，また，その震胞が発 生してからの経過時間も異なり, 検索された時点での落 胞の状熊が必ずしも一定でなかったことにも原因がある ように思われる. したがって本研究では主として平㚬値 についての血清との比較にとどまったが，今後さらに症 例を加えて検索し，統計学的に検討するとともに，それ と峦壁を含む周囲組織の変化との関連についてす追及し ていきたい.

\section{6. 結語}

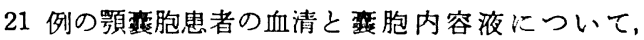
Disc 電気泳動による蛋白分画, ならびに総蛋白, cholesterol, hexosamine および電解質の定量を行ない, 以 下の結果を得た。

1）震胞内容液の Disc 電気泳動による蛋白分画の泳 動像を血清蛋白のそれと比較すると，特に globulin 位 
で各分画の分離が不明瞭で，また分画数の減少が揞明で あった。

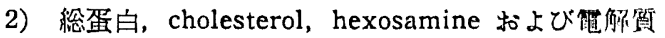
の定量值は，萖胞性エナメル上皮蕾内容液の総蛋白㯰を

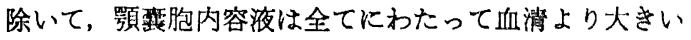
偏差を示した。

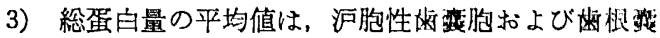
胞では血清よりもやや高く，術後性上顎焉胞では注ば筞 しく, エナメル上皮脡ではやや低かった。

4）総 cholesterol の平均値は，沪胞性胸，腿

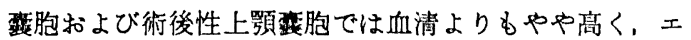
ナメル上皮腫ではほほ等しかった. cholesterol ester 比 は，エナメル上皮缠を含む全ての亯胞で血清の約 70\% と低かった。

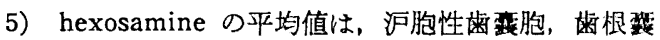
胞扰よび術後性上䫕胞では血清よりも高く、エナメル 上皮腫でほぼ等しかった。

6）内容液の $\mathrm{Na}$ 就よびKの平均值は全体的に血清よ りも低い㑯向にあり，特に Naは血清より低いものが大 多数であった.

7） $\mathrm{Cl}$ の平均值は，沪胞性歯震胞では血清よりるや や低い傾向を示し，歯根变胞拉よび術後性上罰露胞では 逆にやや高い傾向を示し，エナメル上皮腫ではほぼ等し かった.

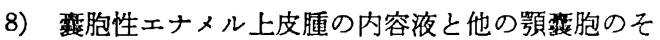
れとは電気泳動像, 総蛋白量, 総 cholesterol 量および hexosamine 量などの面でやや異なっており，それらを 比較検討することが両者の鑑別診断に役立つ可能性があ るよらに思われた。

9）以上の結果から，顎稖胞内容液の生化学的性状は 血清のそれを直ちに反映しているとは言いがたく，覆胞 の長年にわたる経過の間に, 内容液は蟹壁を含む周囲組 織からいろいろな影響を受けるものと思われる。しかし， その metabolism は, 醉素活性の測定結果を併せ考える 之，多分に静的なるの之思われた。

稿を終るに当り，䅂始御指導と御校閲を戴いた伊藤秀夫教授， 中央検査部生化学坂岸良克講師，ならびに御教示と御校閲を教 いた生化学教室佐々木哲教授炕心から感謝いたします。

また，御援助，御協力下さった中央検査部生化学の方々，な らびに第 2 口胫外科学教室の諸兄に心から感謝いたします.

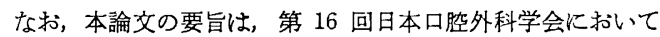
発表した.

\section{文献}

1) Toller, P. : Origin and growth of cyst of the jaws. Ann R Coll Surg 40:306-336 1967.

2）深江 一：口腔底二発生セル所謂 Epidermoid zyste, 一例, 泣二其内容ノ化学的検査. 耳咽喉科 4:372 1931 .

3）中村正二郎：ディスク電気泳動. 臨床病理 特集 $11: 77$ 931968 .

4) Lowry, O.H., Rosebrough, N.J., Farr, A.L. and Randall, R. J. : Protein measurment with the Folin phenol rengent. J Biol Chem $193: 265-2751951$.

5) Daughaday, W. H., Lowry, O. H., Rosebrough, N. J. and Fields, W.S. : Determination of cerebrospinal lluid protein with the Folin phenol reagent. J Lab Clin Med 39 : 663-665 1952.

6) Zak, B., Dicknman, R.C., White, E. G., Burnett, H. and Cherney, P.J. : Rapid estimation of free and total cholesterol. Am J Clin Path $24: 1307-1315$ 1954.

7) Boas, N.F. : Method for the determination of hexo samine in tissues. J Biol Chem 204:553-563 1953.

8) Schales, O, and Schales, S. S. : A simple and accurate method for the determination of chloride in biolog $\mathrm{i}$. cal fluids. J Biol Chem 140:879-884 1941.

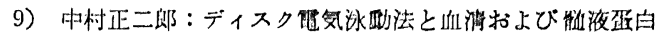
饮。聂新医学 19:827-818 1964.

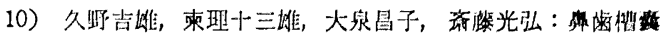
胞の 2 症例について. 日口外就 $16: 406-4101970$.

11）茂木五郎，中村正二郎，根上妾文：ディスク泳動法によ る諸体液疍白の分析. 生物物理化学 11：15-22 1965.

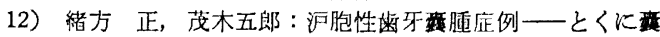
腫内容液の蛋白分画注つて—. 耳臨床 $57: 411$ 4151964.

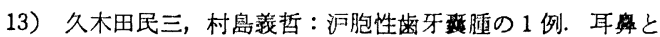
臨休 $7: 23-271961$.

14）饭沼寿孝，宮川晃一，佐藤恒正：巨大な歯根索朠の一症 例. 耳喉誌 $41: 665-6681969$.

15) Tchedomir, I., Kosanovitch, M., Banovitch, N. and Milutinovitch, M. : Formations kystiques du sinus maxillaire. Lille Med 10:647-652 1965.

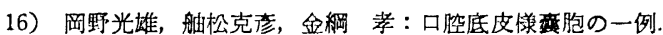
日口外誌 $7 ; 1861961$.

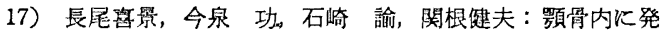
生した類皮様胞の 1 例. 齿科学報 $62: 39-431962$.

18）形浦昭克，西野目雅腈，川口栄三：喉頭监に発生した Epidermoid cyst の 1 例—特に胞内容液の脂質分 画について一耳奥踟床 $59:$ 48-52 1966.

19）吉田滋美：额骨内に発生する落胞の生成機序に関する生 化学的研究. 科学報 62: 97-105 1962.

20）石川梧朗, 秋吉正豊：口腔病理学第 1 巻. 水米薈店, 京 都, 1971, p. 388 .

21) Councell, A.C. : The pathology of dental cysts. Br Dent J $53:$ 69-75 1932.

22) Darlington, C.G. : "So-called" tumors of special interest to the dentist. Dent Cosmos $75: 652-662$ 1933.

23) Thoma, K.H. and Goldman, H. M. : Oral Pathology. ed 5. Mosby Co, St Louis, 1960, p 418.

24) Jacobs, M. H. and Stone, H. : Cysts of the jaws. Am J Orthod \& Oral Surg $26: 690-7111940$.

25) Shear, M. : Cholesterol in dental cysts. Oral surg Oral Med \& Oral Path 16:1465-1473 1963.

26) Browne, R. : The origin of cholesterol in odontogenic cyst in man. Arch oral Biol $16: 107-1131971$.

27) Foldes, F.F.and Murphy A. J. : Distribution of cholesterol, cholesterol esters and phospholipid phosphorus in normal blood. Proc Soc Exp Biol Med 62 : 215-218 1946.

28) Kirsch, T. : Über das Verhalten des Cholesterins. piegels im Blut nach operative Behandlung von Kieferzysten. Stoma 9:115-124 1956.

29) Hertz, R.S. : An investigation into the relationship 
between blood serum cholesterol and the cholesterol content of periapical dental lesions. J S Calif St Dent Assos $31:$ 41-46 1963.

30) Winzler, R. J. : Method of biochemical analysis. Vol 2. D. Glick Interscience, N.Y., 1960, p 290-294.

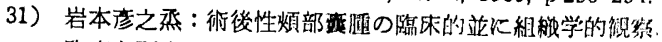
臨床と研究 $24: 220-2241947$.
32) Dische, Z, and Shettles, L. B. : A specific color reac tion of metylpentoses and a spectrophotometric micromethod for their determination. J Biol Chem $175: 595-6031948$.

33) Winzler, R. J. : Method of biochemical analysis. Vol. 2. D. Glick Interscience, N Y., 1960 p 294-296. 